\title{
Научно-инновационный комплекс как один из базовых факторов трансформации каркаса расселения на примере СТП Свердловской области. Предпосылки включения научно-инновационного комплекса в базовые факторы трансформации региональной системы расселения
}

\author{
Г.И.Кулешова, ОНИР ГИПРОНИИ РАН, Москва
}

Вызовы, вставшие перед страной в связи с переходом экономики страны на инновационный путь, выводят на новый уровень градоформирующую роль научно-инновационного комплекса страны.

Системы расселения регионов РФ вкупе с территориальной структурой экономики формировались преимущественно на индустриальном этапе развития страны в тесном взаимодействии с производством. При переходе к рыночным принципам организации хозяйства структура экономики регионов, в значительной мере разрушенная в 90-е годы прошлого века, претерпела существенные изменения, что обусловило высокую степень пространственной неоднородности экономического роста в регионах, изменение демографической ситуации в муниципальных образованиях, стало причиной деградации части внутрирегиональных систем расселения. Инновационный путь развития меняет роль различных типов поселений в экономике, предъявляя новые требования и к качеству жизни на территории, и к качеству трудовых ресурсов на местном рынке труда. Трансформация экономики, ориентированной на модернизацию и инновационный путь развития, должна осуществляться с учётом обеспечения условий для диффузии инноваций на пространственном уровне. Вопросы интенсификации инновационной деятельности приобретают важное значение для повышения качества устойчивого развития как в целом Свердловской области, так и её промышленно-производственного каркаса. Основным драйвером преобразований является научно-инновационный комплекс региона, а местом активизации - территории его преимущественного размещения и развития ${ }^{1}$.

Ключевые слова: трансформация системы расселения, инновационная экономика, научно-инновационный комплекс, фундаментальная, прикладная и корпоративная наука, университеты, технопарки, индустриальные парки, высокотехнологичное производство.

${ }^{1}$ Настоящая статья написана на основе раздела «Научно-инновационный комплекс Свердловской области» НИР «Внесение изменений в схему территориального планирования Свердловской области» (ОАО «ГИПРОГОР», Москва, 2020 год. Заказчик: Министерство строительства и развития инфраструктуры Свердловской области, госконтракт № 0КЭФ-2019-07 от 28.10.2019).
Scientific and Innovative Complex as One of the Basic Factors of Transformation of the Settlement Framework on the Example of the Scheme of Territorial Planning of the Sverdlovsk Region. Prerequisites for the Inclusion of the Scientific and Innovative Complex in the Basic Factors of Transformation of the Regional Settlement System

G.I.Kuleshova, ONIR GIPRONII RAN, Moscow

The challenges facing the country in converting the country's economy to an innovative path bring to a new level the cityforming role of the country's scientific and innovative complex. The settlement systems of the regions of the Russian Federation, together with the territorial structure of the economy, were formed mainly at the industrial stage of the country's development in close cooperation with production. During the transition to market principles of economic organization, the structure of the regional economy, which was largely destroyed in the 90 s of the last century, has undergone significant changes, causing a high degree of spatial heterogeneity of economic growth in the region, changing the demographic situation in municipalities, and has caused the degradation of some intraregional settlement systems. The innovative way of development changes the role of various types of settlements in the economy, making new demands on both the quality of life on the territory and the quality of labor resources in the local labor market. The transformation of an economy focused on modernization and innovative development should consider the provision of conditions for the diffusion of innovations at the spatial level. Issues of intensification of innovation activities are becoming important in order to improve the quality of sustainable development in the Sverdlovsk region as a whole, as well as the industrial and production framework. The main driver of transformation is the scientific and innovative complex of the region, and the place of activation is the territory of its primary location and development.

Keywords: transformation of the settlement system, innovative economy, scientific and innovative complex, fundamental, applied, and corporate science, universities, technoparks, industrial parks, high-tech production

В последние годы был принят ряд директивных документов, в которых получили отражение вызовы, вставшие перед страной в связи с переходом экономики страны на 
инновационный путь². Эти законопроекты выводят на новый уровень градоформирующую роль научно-инновационного комплекса страны, поскольку инновационная экономика имеет существенное отличие по сравнению с индустриальным периодом, обусловленное её связями с территориями: «Инновационная экономика - это своего рода процесс "индустриализации мышления"», для эффективной реализации которого необходимо, чтобы на компактной территории поддерживалась высокая плотность мышления и разнообразие видов деятельности» [1].

Переход на инновационный путь развития становится серьёзной предпосылкой для трансформации региональной системы расселения, так как меняется роль различных типов поселений в экономике, предъявляются новые требования к качеству жизни на территории и, главное, - к качеству трудовых ресурсов на местном рынке труда. Наиболее квалифицированные кадры предпочитают уезжать за пределы региона, если в регионе нет крупного центра, являющегося генератором инноваций и обеспечивающего комфортность проживания. В настоящее время разрыв между центрами и периферией может усиливаться не в результате количества сконцентрированных трудовых ресурсов, обеспечивающих индустриальное развитие, а в результате наличия или отсутствия необходимых компетенций этих трудовых ресурсов. Как пишет Жирнель А.В., «... и город может являться периферией, если он не притягивает интеллектуальные ресурсы, не генерирует инновационные продукты и технологии» [2]. Другими словами, в настоящее время деструкция рынка труда может сохраняться и в условиях притока инвестиций и развития производства вследствие несоответствия квалификации местных трудовых ресурсов требованиям современных технологий, причём не только технологий высоких переделов, но и новым технологиям добычи и переработки ресурсов.

Поскольку региональная экономика [3] рассматривает «регион как социально-экономическую систему, состоящую из ряда подсистем, её развитие должно соответствовать не только экономическим, но и социальным, экологическим, культурно-образовательным целям, а её территориальная структура не должна входить в противоречия со сложившейся в регионе системой расселения» [4, с. 43]. Однако, учитывая, что экономическая структура в регионе может изменяться достаточно быстро, а система расселения является более инертной, возникновение таких противоречий представляется неизбежным [5, с. 529].

Экономика Свердловской области (далее С0) носит исторически сложившийся индустриальный характер. Наличие в области разнообразных минерально-сырьевых ресурсов пре- допределило развитие отраслей тяжёлой промышленности, ведущими из которых являются цветная и черная металлургия, машиностроение и металлообработка, электроэнергетика.

Анализ реализации предложений действующей СТП Свердловской области ${ }^{3}$ в сопоставлении с существующей ситуацией показал, что структурная перестройка экономики в процессе рыночных преобразований обусловила высокую степень пространственной неоднородности экономического роста территории в регионе, привела к изменению демографической ситуации в муниципальных образованиях, стала причиной деградации части внутри региональных систем расселения, ранее намеченных в СТП к активному развитию. Более того, существующая ситуация практически обнулила принцип равномерности пространственного развития, задекларированный в СТП-2007. На переломе 2000-х регион с жёсткой промышленной специализацией, огромным запасом накопленных основных производственных фондов и большим количеством моногородов оказался даже в более глубоком кризисе, чем другие уральские регионы [6].

В последние годы в СО реализуется индустриально-модернизационная модель развития экономики [7], предусматривающая структурную диверсификацию промышленности в результате возникновения и роста ряда новых и новейших наукоёмких производств, активизации модернизационных процессов в базовых традиционных отраслях, а также угасания и отмирания устаревших.

Трансформация экономики, ориентированной на модернизацию и инновационный путь развития, должна осуществляться с учётом обеспечения условий для диффузии инноваций [8] на пространственном уровне. Вопросы интенсификации инновационной деятельности приобретают важное значение для повышения качества устойчивого развития как в целом Свердловской области, так и её промышленно-производственного каркаса. Основным драйвером преобразований является научно-инновационный комплекс региона, а местом активизации - территории его преимущественного размещения и развития.

\section{Основные характеристики научно-инновационного комплекса СO}

В целом, как показали исследования [8], научно-инновационный комплекс территорий в полном виде включает:

- образовательный комплекс в виде университетов и технических вузов;

- научно-исследовательский комплекс в виде организаций академической и прикладной науки;

- научно-технический комплекс в виде подразделений НИОКР в составе крупных корпораций, государственных

\footnotetext{
${ }^{2}$ Такие как: «Стратегия развития информационного общества в Российской Федерации на 2017-2030 годы», утверждённая Указом Президента Российской Федерации от 09 мая 2017 г. № 203; «Стратегия научно-технологического развития Российской Федерации», утверждённая Указом Президента Российской Федерации от 01 декабря 2016 г. № 642; Программа «Цифровая экономика Российской Федерации», утверждённая распоряжением Правительства Российской Федерации от 28 июля 2017 г. №1 632-р. и ряд других.

${ }^{3}$ Свердловская область. Схема территориального планирования / ОАО "УРАЛГРАЖДАНПРОЕКТ", научный руководитель Г.В. Мазаев. - Екатеринбург, 2007.
} 
и частных производств, реализующий технологии двойного назначения.

Рейтинги инновационности регионов, проводимые РИА «Рейтинг», подтверждают, что высокие места обусловлены двумя факторами:

- наличием университетов, академгородков, наукоградов, корпоративных и ведомственных НИИ, КБ, НПО, которые обеспечивают теоретическую базу иновационно-технологического развития;

- наличием в регионе исторически развитого, высокотехнологичного по любым мировым меркам, ядерного и военно-оборонного кластера, особых экономических зон и относительно новых авто- или аэростроительных кластеров, которые обеспечивают платформу для внедрения теоретических изысканий на практике.

В основе предпосылок развития эффективной инновационной деятельности в СО лежат три составляющих:

- шестой по численности персонала научно-технический комплекс в стране, включая Ур0 РАН - форпост осуществления ориентированных фундаментальных исследований, которые стали императивом времени;

- значительный по масштабу образовательный комплекс как центр формирования компетенций;

- активно формирующаяся инновационная инфраструктура.

Всего в научно-техническом комплексе С0, по данным Свердловскстата на 2018 год, занято 20528 человек, 8877 из них исследователи 4 . В научной сфере работают 645 докторов и 1992 кандидата наук. Уро РАН объединяет 21 академический научный институт, на территории области находятся 111 научно-исследовательских, проектных, технологических, конструкторских и других, выполняющих научные исследования и разработки организаций.

В С0 25 вузов, где обучается более 121 тыс. студентов (более $36 \%$ от общего числа студентов в Уральском федеральном округе). Федеральный университет - ФГАОУ ВО «Уральский федеральный университет имени первого Президента России Б.Н. Ельцина» - является ядром инновационной активности и структурообразующим элементом основных промышленных кластеров региона.

В СО имеется в наличии высокотехнологичный по всем международным меркам бизнес - базовые предприятия крупнейших корпораций и ВПК с развитой сферой НИОКР как необходимой частью обеспечения конкурентоспособности самой наукоёмкой и инновационной по самой своей сути продукции, 35 промышленных предприятий выполняют научно-исследовательские и опытно-конструкторские работы. Эти предприятия относятся к так называемым стратегическим

${ }^{4}$ Количество научно-технических работников сократилось по сравнению с 2016 годом на 8\%, а количество исследователей - на 14\%. Это очень серьёзные потери, учитывая задачи, поставленные руководством страны по построению инновационной экономики, хотя Научно-технический комплекс Свердловской области остаётся пятым по величине в стране. инноваторам, определяющим уровень развития отрасли, региона и страны, устанавливающим долгосрочные тенденции технологического развития и конкурентоспособность на национальных и мировых уровнях.

Особенностью научно-инновационного комплекса Урала является тесная спайка научной и производственной составляющих. Уральские предприятия ОПК не только постоянные партнёры институтов Ур0 РАН, поскольку они более инновационны и заинтересованы в контактах с наукой, чем гражданские заводы [9], но и сами входят в число инновационных лидеров СО.

В СО активно формируется инновационная инфраструктура, в основе которой бизнес-инкубаторы, технополисы, индустриальные парки. Однако нельзя не отметить особенности, связанные с высокой производственной ориентированностью инновационной инфраструктуры. Это в полной мере относится не только к технопаркам, но и к бизнес-инкубаторам. Так, по существу, только два технопарка - Университетский и Академический, оба в Екатеринбурге - можно в полной мере отнести к инновационным предприятиям как содержащим стартапы. Остальные технопарки являются, по сути, площадками для размещения малого бизнеса, в большинстве своём внедряющего инновационные технологии, но не производящего их.

В целом, научно-инновационный комплекс Свердловской области имеет полный, объединённый и расширенный характер в большей степени, чем научно-инновационные комплексы других регионов.

Роль опорных территорий научно-инновационной деятельности и предложения в трансформации системы расселения Свердловской области

Экономический потенциал региона на территории области размещён крайне неравномерно. Екатеринбургская агломерация концентрирует около $43 \%$ населения области, $47 \%$ промышленного производства и почти 75\% общего объёма инвестиций в основной капитал. В целом же Екатеринбург с окружающими его городами, Нижний Тагил с сателлитами, Каменск-Уральский и северный куст городов (город Серов) в совокупности концентрируют 65\% населения региона, $83 \%$ промышленного производства, 92\% общего объёма инвестиций в основной капитал. Здесь проводится ускоренная комплексная технологическая модернизация наиболее значимых и включённых в глобальные рынки базовых отраслей, модернизация ключевых предприятий и секторов экономики в рамках инвестиционных программ в атомной и традиционной энергетике, инвестиционных программ федеральных ведомств, опережающими темпами разворачивается сектор услуг с появлением новых «локомотивов» роста: сложных деловых услуг (финансовые и банковские услуги, страхование, PR, юридические услуги), технологических сервисов, выделяемых как обособленный вид деятельности из промышленного сектора. 
Очевидно, что научно-технический потенциал, как и в целом объекты научно-инновационного комплекса, тяготеет по самой своей сути к экономически насыщенным территориям ${ }^{5}$. Однако не все научно-технические организации и предприятия можно отнести к безусловному инновационному циклуб. Анализ размещения основных объектов научно-инновационного комплекса региона позволит выявить его структурообразующую роль в трансформации системы расселения региона.

По отношению к инновациям можно отметить четыре типа компаний: стратегические инноваторы, периодические инноваторы, модификаторы и пользователи инноваций [8]. Предприятия, которые можно отнести к составляющей объединённого научно-технического комплекса Свердловской области, являются по сути своей стратегическими или, по меньшей мере, периодическими инноваторами и вследствие этого активными участниками инновационной деятельности [8]. Базовые территории локализации основных акторов научно-инновационного комплекса СО рассмотрены ниже.

1. Екатеринбург является центром проведения научных исследований - как фундаментальных, так и прикладных. Здесь сосредоточен основной массив научно-исследовательских, проектных, технологических, конструкторских и других выполняющих научные исследования и разработки организаций. Президиум Ур0 РАН и его институты также расположены здесь, на территории Академического городка. В столице региона по меньшей мере восемь базовых промышленных предприятий технологий двойного назначения полного инновационного цикла (от разработки и проектирования до готовой продукции), таких как Машиностроительный завод имени М.И. Калинина, Уральский завод транспортного машиностроения и другие постоянные участники мирового рынка. В агломерации размещается более $96 \%$ приведённого контингента студентов вузов СО.

В состав территорий Екатеринбургской агломерации входит Верхняя Пышма (город в Свердловской области), опорная территория ряда крупнейших предприятий - успешных участников мирового рынка: Уральской горно-металлургической компании с системообразующим предприятием $\mathrm{AO}$ «Уралэлектромедь», 000 «Уральские локомотивы», 0АО «Уралредмет». При этом в Верхней Пышме в 2014 году был организован первый негосударственный технический вуз - Технический университет Уральской горно-металлургической компании. Это новое явление в отечественном образовании, возникшее

${ }^{5} 0$ ходе реализации региональных проектов «Развитие кадрового потенциала в сфере исследований и разработок в Свердловской области» и «Развитие научной и научно-производственной кооперации в Свердловской области», направленных на достижение целей и целевых показателей национального проекта «Наука» (источник: http://mpr.midural.ru/natsionalnye-proekty/ file://C:/Users/Администратор/Downloads/Realizacia_n.p_Nauka\%20(3.pdf).

${ }^{6}$ Оценка потенциальной инновационности промышленного потенциала - «Перечень наукоёмких технологий и товаров» (США), оценка научного потенциала - The European Strategy Forum on Research Infrastructures, НТИ РФ в ответ на потребности крупных производственных компаний, не удовлетворённых уровнем технической подготовки молодых специалистов. «Технический университет УГМК» является единственным негосударственным вузом России, который создан на базе университетской кафедры и промышленного предприятия. Это одна из 77 утверждённых властями России федеральных инновационных площадок (декабрь 2017 года). С 2013 года в Университете ежегодно проходят курс повышения квалификации несколько тысяч сотрудников компаний России.

2. Заречный (город в сорока километрах от Екатеринбурга): здесь находится Институт реакторных материалов (ИРМ) - третий в стране исследовательский ядерный центр, специализирующийся на работах в сфере радиационного материаловедения, физики твёрдого тела, производит более десяти видов изотопов, используемых в промышленности и медицине. Размещён филиал НИУ мИФИ.

3. Нижний Тагил, где расположено восемь уникальных научно-производственных предприятий полного инновационного цикла, таких как АО «Научно-производственная корпорация «Уралвагонзавод», АО «Химический завод «Планта», ОАО «Уральское конструкторское бюро транспортного машиностроения», являющихся структурными звеньями оборонного комплекса страны. Уникальными ключевыми компетенциями в области испытания вооружения, военной техники и боеприпасов обладает Нижнетагильский институт испытания металлов. В Нижнем Тагиле более десяти вузов - филиалов ведущих университетов Москвы, С.-Петербурга и УрФУ, 18 политехнических колледжей.

4. ЗАТО Лесной: «Электрохимприбор»: военная продукция, стабильные изотопы, гражданская продукция, реализация конверсионных проектов, имеет статус ТОСЭР.

5. ЗАТО Новоуральск. В отраслевом научно-промышленном комплексе занято 52 доктора и кандидата наук, основные акторы инновационной деятельности: ПАО «Уральский электрохимический комбинат», мировой лидер разделительного производства изотопов урана, Новоуральский приборный завод, 000 «Экоальянс», 000 «Завод Медсинтез». Имеет статус ТОСЭР.

6. Каменск-Уральский: ОАО «Уралпромэнергопроект», проектно-исследовательский актив 000 «ЕвроСибЭнергоинжиниринг» - прямой стратегический инноватор. Другие градообразующие предприятия города - ОАО «СинТЗ», РУСАЛ, ОАО «КУМЗ», ПО «Октябрь» - периодические инноваторы инновационного цикла, как и многие другие предприятия Урала, тесно связанные с заказами оборонного комплекса, госкорпорациями добывающего сектора.

7. Серов. Серовский механический завод также относится к периодическим инноваторам: разработка и производство широкого спектра промышленного инструмента для горнодобывающей промышленности, нефтяной промышленности, геологоразведки, военной продукции, входит в российскую корпорацию «Ростех». 
В отношении развития инновационной деятельности на базе научно-образовательного комплекса очевидно безусловное доминирование столичного комплекса университетов и институтов. Количество обучающихся по программам высшего образования на территориях других муниципальных образований по сути ничтожно по сравнению с Екатеринбургом, кроме того, практически во всех случаях - это дистанционный тип образования по заочной форме в филиалах УрФУ или ведущих вузов Москвы, С.-Петербурга. Только три территории из выделенных, за исключением Екатеринбурга и агломерации, подтвердили существенность отнесения к инновационным территориям по фактору наличия собственных вузов: Нижний Тагил, ЗАТО Лесной и ЗАТО Новоуральск.

К территориям с большим инновационным потенциалом можно отнести территории 0ЭЗ, поскольку главная цель их создания - обеспечить развивающийся высокотехнологичный бизнес финансово доступными и хорошо оборудованными площадями с транспортной и инженерной инфраструктурой.

Таких территорий в Свердловской области на настоящий момент две: Верхняя Салда (Нижний Тагил) и Уктус (Екатеринбург) - обе относятся к $0 Э 3$ «Титановая долина». Приоритетные отраслевые направления 0Э3: аэрокосмическая отрасль, изделия из титана, машиностроение любых отраслей (производство средств производства, производство компонентов). Площадка в Верхней Салде, организованная первоначально по типу «гринфилд», в настоящее время позволяет создать условия для ускорения реализации продукции ПАО

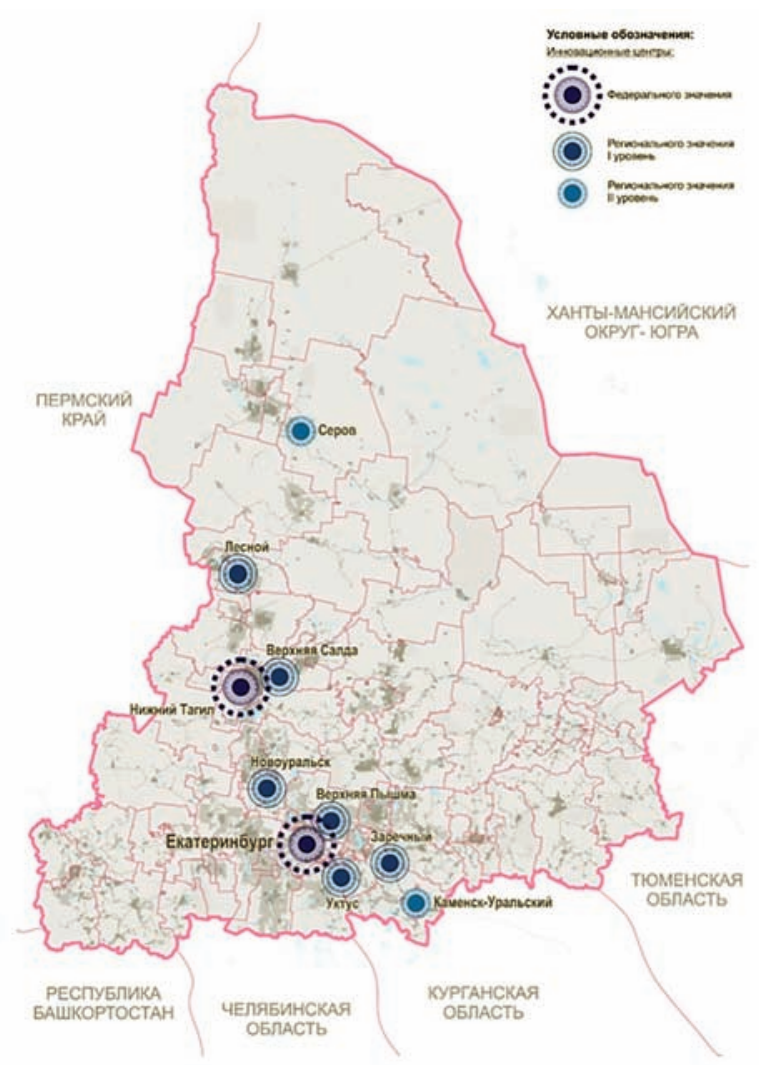

Pис. 1. Опорные территории инновационной сферы в Свердловской области. Схема ОАО «ГИПРОГОР»

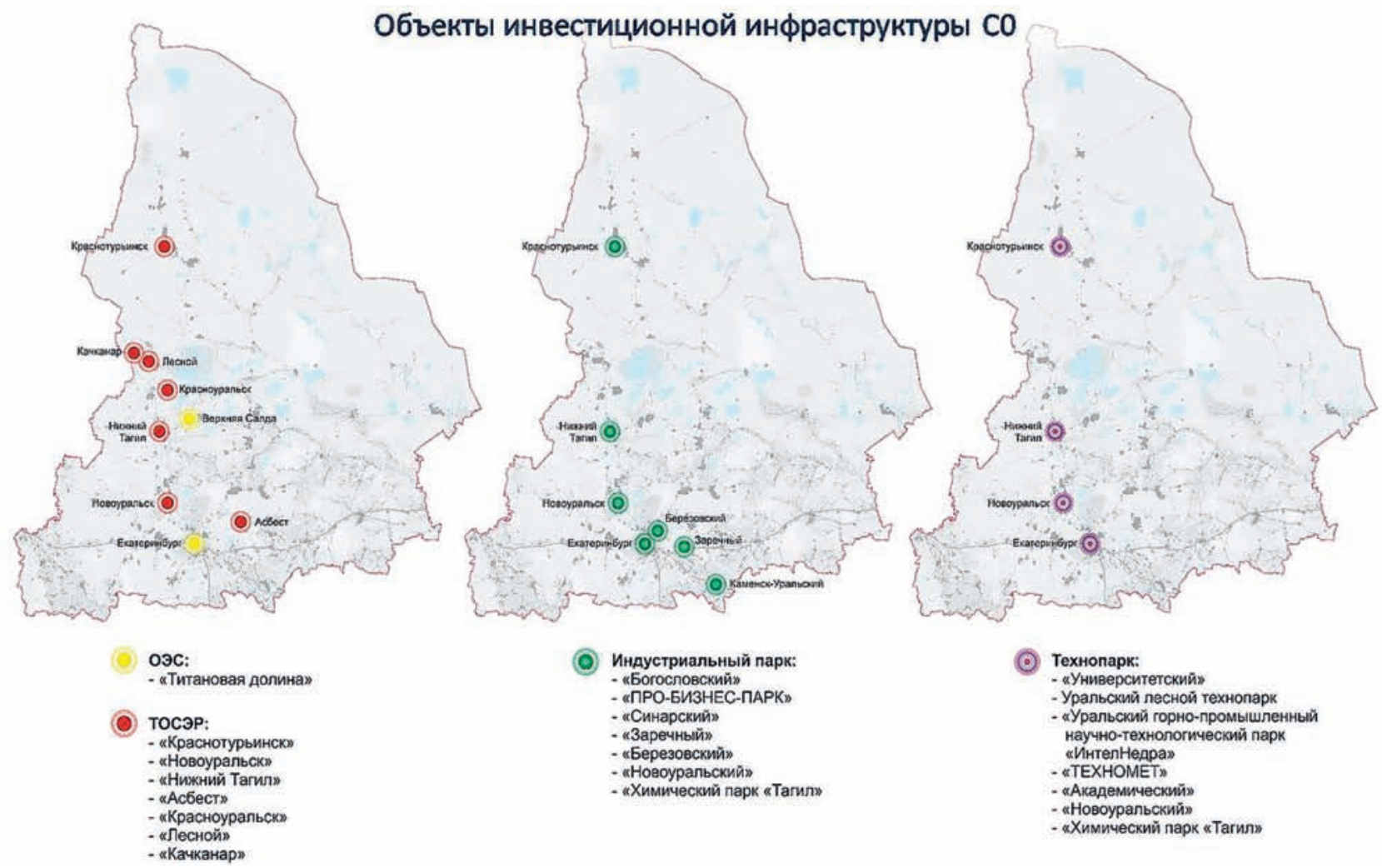

Рис. 2 Схемы размещения планируемых объектов инновационного назначения по инвестиционным программам Свердловской области. Схема ОАО «ГИПРОГОР» 
«Корпорация ВСМПО-АВИСМА» - металлургической компании, мирового лидера по производству титана и изделия из него. На площадке Уктус под Екатеринбургом типа «браунфилд/ гринфилд» с готовой, реконструируемой и строящейся инфраструктурой в 2018 году завершено строительство производственного комплекса для сборки самолётов, на территории организована взлётно-посадочная площадка.

Таким образом, основная инновационная деятельность в С0 агрегирована на территориях с базовым промышленным,

Таблица 1. Планируемые к размещению объекты инновационного назначения в инвестиционных программах Свердловской области

\begin{tabular}{|c|c|c|}
\hline № & Наименование & Местоположение \\
\hline \multicolumn{3}{|c|}{ Технопарки } \\
\hline 1. & $\begin{array}{l}\text { «Уральский горно-промышленный } \\
\text { НТП «ИнтелНедра» }\end{array}$ & Екатеринбург \\
\hline 2. & Уральский лесной технопарк ФГБОУ ВПО «УГЛТУ & Екатеринбург \\
\hline 3. & Научно-производственный парк «ТЕХНОМЕТ» & Екатеринбург \\
\hline 4. & Технологический парк «Приборостроение» & Екатеринбург \\
\hline 5. & Технопарк «Авиценна» & Екатеринбург \\
\hline 6. & Технопарк «Евразийский» & Екатеринбург \\
\hline 7. & Технопарк «Энергия» & Екатеринбург \\
\hline 8. & Технопарк Локомотив & Верхняя Пышма \\
\hline 9. & Промышленный комплекс «Верхнепышминский» & ГО Верхнепышминский \\
\hline 10. & Технопарк «Синарский» & Каменск-Уральский \\
\hline 11. & $\begin{array}{l}\text { ООО Технопарк РМЗ } \\
\text { (Режевского механического завода) }\end{array}$ & Peж \\
\hline 12. & Технопарк Первомайский, производственный & пос. Первомайский \\
\hline 13. & $\begin{array}{l}\text { Промзона планировочного района «Зелёная } \\
\text { долина" }\end{array}$ & Березовский \\
\hline \multicolumn{3}{|c|}{ Индустриальные парки } \\
\hline 1. & Индустриальный парк «Солнечный» & Екатеринбург \\
\hline 2. & «А Плюс Парк Екатеринбург» & Екатеринбург \\
\hline 3. & "UL-park»( (UralLogistics) & Екатеринбург \\
\hline 4. & «DEGA-Екатеринбург» & Екатеринбург \\
\hline 5. & Индустриальный парк «Новосвердловский» & Екатеринбург \\
\hline 6. & Индустриальный парк «Екатеринбург» & Екатеринбург \\
\hline 7. & Индустриальный парк «Уралмаш» & Екатеринбург \\
\hline 8. & Индустриальный парк «ЕКАД» & Екатеринбург \\
\hline 9. & Индустриальный парк «Режевской» & РежевскоймГО \\
\hline 10. & Уральский индустриальный парк & пос. Полевой \\
\hline 11. & Муниципальный индустриальный парк «Заречный» & ГО Заречный \\
\hline 12. & Индустриальный парк «Новоуральский» & НовоуральскийГО \\
\hline 13. & Индустриальный парк «Магнитка" & ГО Первоуральск \\
\hline 14. & Частный индустриальный парк «Гринпарк» & Асбестовский ГО \\
\hline 15. & Индустриальный парк «Исетскиий» & ГО Среднеуральск \\
\hline 16. & Индустриальный парк «Урал» & пос. Бобровка \\
\hline 17. & Индустриальный парк «Богословский» & Краснотурьинск \\
\hline \multicolumn{3}{|c|}{ TOCЭP } \\
\hline 1. & ТОСЭР «Верхняя Тура» & ГО Верхняя Тура \\
\hline 2. & ТОСЭР "Асбест» & ГО Асбест \\
\hline 3. & ТОСЭР «Качканар» & ГО Качканар \\
\hline 4. & ТОСЭР «Нижний Тагил» & ГО Нижний Тагил \\
\hline \multicolumn{3}{|c|}{ Инновационный территориальный кластер } \\
\hline 1. & Креативный научно-образовательный кластер & Екатеринбург \\
\hline 2. & Научно-образовательный кластер & Екатеринбург \\
\hline 3. & $\begin{array}{l}\text { Инновационный научно-технологический центр } \\
\text { «Татищев» }\end{array}$ & Екатеринбург \\
\hline 4. & $\begin{array}{l}\text { Инновационный медицинский кластер } \\
\text { «Академический» }\end{array}$ & Екатеринбург \\
\hline
\end{tabular}

научно-техническим и образовательным ресурсами: Екатеринбургская агломерация, куда входят Верхняя Пышма, Зареченск и Уктус, агломерация Нижнего Тагила с Верхней Салдой, ЗАТО Новоуральск, ЗАТО Лесной, Каменск-Уральский, Серов.

Поскольку, как было отмечено выше, особенностью научно-инновационного комплекса Свердловской области является его индустриальная направленность, опорные территории инновационной сферы (рис. 1) были ранжированы по уровню включенности ключевых акторов инновационной деятельности - высокотехнологичных предприятий полного инновационного цикла - в масштабы рынков. Вузы, научнотехнический комплекс, технопарки, индустриальные парки, $0 Э 3$ выступали в ранжировании вторым эшелоном. Уровень инновационных центров СО:

- федерального значения: Екатеринбург (Екатеринбургская агломерация), Нижний Тагил;

- регионального значения первого уровня: ЗАТО Новоуральск, ЗАТО Лесной, Заречный, Верхняя Пышма, Верхняя Салда, Уктус;

- регионального значения второго уровня: КаменскУральский, Серов.

В настоящее время на территории Свердловской области проводится реализация трёх программ в рамках национального проекта «Наука», в частности, регионального проекта «Кооперация» в части создания Уральского межрегионального научно-образовательного центра мирового уровня «Передовые промышленные технологии» ${ }^{7}$. Излишне говорить, что эти программы в наиболее полном объёме реализуются на обозначенных выше территориях.

С выделенными опорными территориями развития инновационной деятельности связана активность областных инвестиционных программ. Это касается создания и развития технопарков, индустриальных парков, ТОСЭР и $0 Э 3$ (рис. 2). Из семи городов, отмеченных как ТОСЭР, три - Краснотурьинск, ЗАТО Новоуральск и ЗАТ0 Лесной - уже имеют этот статус и являются инновационными центрами Свердловской области. На схемах размещения технопарков и индустриальных парков видно, что все они тяготеют к территориям активной инновационной деятельности. Из семи функционирующих технопарков большинство размещается в Екатеринбургской агломерации.

Планируемые к созданию 13 технопарков и 17 индустриальных парков ${ }^{8}$ также закладываются на опорных территориях инновационной деятельности или в ареале их влияния (табл. 1). Предполагаемое формирование и развитие инновационных кластеров прямо связано со столицей региона как с территорией, наиболее удовлетворяющей требованиям к качеству человеческого капитала.

${ }^{7}$ Инвестиционная стратегии Свердловской области на период до 2015 года / Утверждена Правительством Свердловской области (Постановление от 15 августа 2019 года №535-ПП).

${ }^{8}$ Инвестиционная стратегия Свердловской области на период до 2015 года, утверждённая Правительством Свердловской области (Постановление от 15 августа 2019 года №535-ПП). 
В разработку концепции СТП Свердловской области необходимой составляющей частью включена проблематика территориально-градостроительного обеспечения эффективности инновационной деятельности путём формирования территорий опережающего развития на основе иновационно-активных субъектов экономики: высокотехнологичных производств полного инновационного цикла, университетов, научно-исследовательских центров, технопарковых структур, полифункциональных научно-образовательных комплексов - центрообразующих объектов нового типа. При этом в качестве новой реальности на перспективу принят курс на стабилизацию имеющейся на данный момент численности населённых пунктов северо-востока области.

При разработке направлений трансформации системы регионального расселения учитывалось размещение зон концентрации научно-инновационного комплекса как территорий первостепенного оснащения инструментами развития в целях обеспечения эффективного развития инновационной деятельности (рис. 3). Для территорий СО характерна недостаточность транспортной связности, в то время как для развития инновационной сферы это - одно из важнейших условий. Поэтому

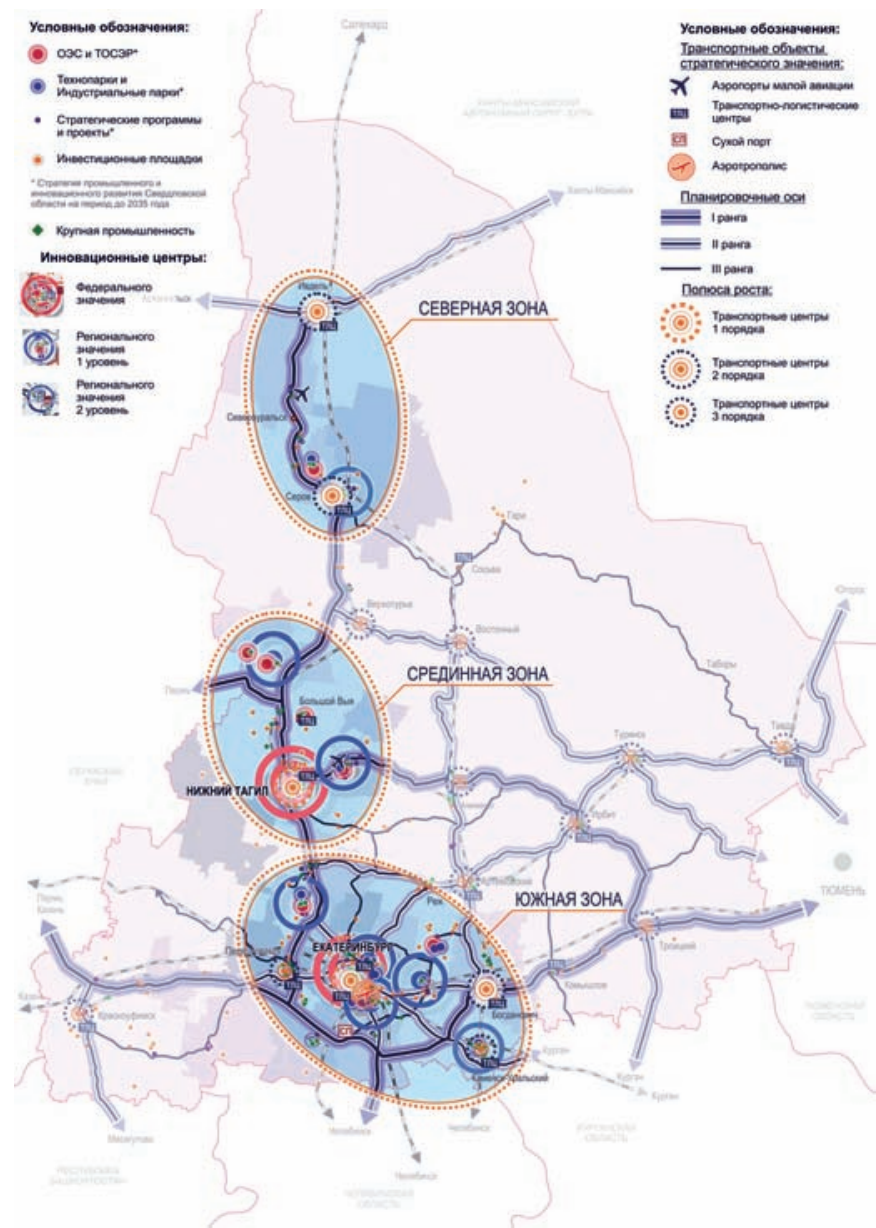

Рис. 3. Зоны размещения базовых территорий развития инновационной деятельности на Схеме системы расселения Свердловской области на перспективу до 2045 года. Схема ОАО ГИПРОГОР ставилась задача обеспечить развитие необходимых фрагментов транспортной инфраструктуры именно на участках связи между населёнными пунктами - инновационными центрами.

Коммуникационный меридиональный коридор связывает зоны концентрации научно-инновационного комплекса региона:

- южную зону с базовой территорией столичной агломерации и тяготеющими сателлитами (Каменск-Уральский);

- срединную зону с центром в Нижнем Тагиле;

- северную зону, протянувшуюся вдоль транспортного коридора между городами Серов и Ивдель.

Южная инновационная зона связывается через федеральные трассы с соседними регионами Урала и страной в целом. Северная инновационная зона выводит инновационные центры юга и срединной части в активно развивающиеся добывающие регионы Севера и Русской Арктики. Насыщение зон инновационной активности неравномерно: очевидно преобладание южной зоны над срединной и северной зонами. Однако все зоны в равной мере обеспечены коммуникационными средствами и для них разработаны меры по развитию социально-экономического комплекса с целью преобразования и модернизации среды для стабилизации численности населения и привлечения высококвалифицированных кадров, необходимых для развития инновационной экономики. Именно в ареалах этих трёх инновационных зон заключены полюса роста территорий.

По мнению академика РААСН главного градостроителя института «УралНИИПроект» (филиал ФГБУ «ЦНИИП Минстроя России») Мазаева Г.В., планировочная структура базовых промышленных городов, являющихся, как показано в настоящей статье, исторически сложившимися инновационными центрами Свердловской области, должна отвечать задачам «новой индустриализации», на основе технологической многоукладности региона. Так, для нормального развития имеющегося потенциала индустриализации необходимо «сохранение в планировочной структуре городов площадок III и IV технологических укладов, восстановление и реновация отдельных объектов IV технологического уклада... проектирование новых функциональных промышленных зон в составе генеральных планов городов в условиях экономической неопределённости по "резервному методу"» [10, с. 13]. Очевидно, что особую роль в процессах «новой индустриализации» могут и должны сыграть такие субъекты инновационной экономики как технопарки и индустриальные парки, которые как раз и могут размещаться на площадках первой группы предприятий.

\section{Лuтература}

1. Щедровицкий, П.Г. Кластерная политика как механизм инновационного развития : Видеолекции [Электронный ресурс] / К.П. Щедровицкий //Материалы Красноярского экономическог форума-2012. - Режим доступа: http://tube.sfu-kras.ru/ system/files/video2/lectures/2012/02/18/shedrovitskiy2012-2/ shedrovitskiy.pdf (дата обращения 02.08.2020). 
2. Жирнель, Е.В. Влияние структурной трансформации экономики на региональную систему расселения [Электронный ресурс] / Е.В. Жирнель // образовательный сайт Refleader. ru. - Режим доступа: http://refleader.ru/jgeotryfsotryfs.html (датаобращения 30.07.2020).

3. Olenev, N. A Normative Dynamic Model of Regional Economy / N. Olenev, N. Mollaverdi // International Journal of Industrial Engineering \& Production Research. - 2011. - Vol. 22. - № 2. - Р. 99-105.

4. Пробст, А.Е. Эффективность территориальной организации производства / А.Е. Пробст. - М. : Мысль, 1965. - 208 с.

5. Региональная экономика : учебник для студентов высших учебных заведений / Видяпин В.И. и др.; под общ. ред. В.И. Видяпина, М.В. Степанова - М. : ИНФРА-М, 2008. - 664 c. ISBN 978-5-16-002973-3.

6. Денисова, 0.Ю. Трансформации территориальной и отраслевой структуры производительных сил Уральского экономического района в постсоветский период: осмысление причин и последствийм / 0.Ю. Денисова // Региональная экономика: теория и практика. - 2015. - Том. 13. - Вып. 7 (382). - С. 39-48.

7. Анимица, Е.Г. Средний Урал на пути к новой индустриализации / Е.Г. Анимица, Я.П. Силин // Экономика региона. - 2013. - № 3. - С. 71-78.

8. Кулешова, Г.И. Территории инноваций: технопаркитехнополисы-регионы науки / Г.И. Кулешова. - М. : Научный мир, 2019. - 368 с.

9. Звёздное небо для науки : интервью с председателем Уральского отделения Российской академии наук Валерием Чарушиным [Электронный ресурс] // Российская Газета. Официальный сайт. 12.07.2012. - Режим доступа: https://rg.ru/2012/07/12/reg-urfo/ charushin.html (дата обращения 14.07.2020).

10. Мазаев, Г.В. Градостроительные условия осуществления «новой индустриализации» / Г.В. Мазаев // Академический вестник УралНИИпроект РААСН. - 2018. - № 1. - С. 10-13.

\section{References}

1. Shchedrovitskii P.G. Klasternaya politika kak mekhanizm innovatsionnogo razvitiya: Videolektsii [Cluster policy as a mechanism of innovative development: Videolectures]. Materialy Krasnoyarskogo ekonomicheskog foruma-2012 [Materials of the Krasnoyarsk Economic Forum-2012]. Access mode: http:// tube.sfu-kras.ru/system/files/video2/lectures/2012/02/18/ shedrovitskiy2012-2/shedrovitskiy.pdf (accessed 02.08.2020).

2. Zhirnel' E.V. Vliyanie strukturnoi transformatsii ekonomiki na regional'nuyu sistemu rasseleniya [The influence of structural transformation of the economy on the regional settlement system]. Obrazovatel'nyi sait Refleader.ru [Educational site Refleader.ru]. Access mode: http://refleader.ru/jgeotryfsotryfs. html (accessed 30.07.2020).

3. Nicholas Olenev \& Naser Mollaverdi. A Normative Dynamic Model of Regional Economy. In: International Journal of Industrial Engineering \& Production Research, 2011, Vol. 22, no. 2, pp. 99-105. (In Engl.)

4. Probst A.E. Effektivnost' territorial'noi organizatsii proizvodstva [he effectiveness of the territorial organization of production]. Moscow, Mysl' Publ., 1965, 208 p.

5. Vidyapin V. I. [et al.]. Regional'naya ekonomika : uchebnik dlya studentov vysshikh uchebnykh zavedenii [Regional economy: a textbook for students of higher educational institutions]. V.I. Vidyapin \& M.V. Stepanov (eds.) Moscow, INFRA-M Publ., 2008, 664 p. ISBN 978-5-16-002973-3.

6. Denisova 0.Yu. Transformatsii territorial'noi i otraslevoi struktury proizvoditel'nykh sil Ural'skogo ekonomicheskogo raiona $v$ postsovetskii period: osmyslenie prichin i posledstviim [Transformation of the territorial and sectoral structure of the productive forces of the Ural economic region in the postSoviet period: understanding the causes and consequences]. In: Regional'naya ekonomika: teoriya i praktika [Regional economy: theory and practice], 2015, Vol. 13, Iss. 7, pp. 39-43. (In Russ., abstr. in Engl.)

7. Animitsa E.G., Silin Ya.P. Srednii Ural na puti k novoi industrializatsii [Middle Urals on the way to new industrialization]. In: Ekonomika regiona [Economy of the region], 2013, no. 3, pp. 71-78. (In Russ., abstr. in Engl.)

8. Kuleshova G.I. Territorii innovatsii: tekhnoparkitekhnopolisy-regiony nauki [Territories of innovations: technoparks-technopolises-regions of science]. Moscow, Nauchnyi Mir, Publ., 2019, 368 p.

9. «Zvezdnoe nebo dlya nauki» : interv'yu s predsedatelem Ural'skogo otdeleniya Rossiiskoi akademii nauk Valeriem Charushinym ["Starry sky for science" : an interview with the chairman of the Ural branch of the Russian Academy of Sciences Valery Charushin]. In: Rossiiskaya Gazeta. Ofitsil'nyi sait. [Rossiyskaya Gazeta. Official site], 12.07.2012. Access mode: https://rg.ru/2012/07/12/reg-urfo/ charushin.html (accessed 14.07.2020).

10. Mazaev G.V. Gradostroitel'nye usloviya osushchestvleniya «novoi industrializatsii» [Urban planning conditions for the implementation of "new industrialization"]. In: Akademicheskii vestnik UralNIIproekt RAASN [Academic Bulletin UralNIIproekt RAASN], 2018, no. 1, pp. 10-13. (In Russ., abstr. in Engl.)

Кулешова Галина Ивановна (Москва). Советник РААСН, академик МААМ (Московское отделение). Ученый секретарь ФГБУН Отделение научно-исследовательских работ ГИПРОНИИ РАН (117971, Москва, ул. Губкина, д. 3. ОНИР ГИПРОНИИ РАН). Эл. почта: e-mail:kuleshgal@yandex.ru.

Kuleshova Galina I. (Moscow). Advisor of RAACS, Academician of the Moscow branch of the International Academy of Architecture. Scientific Secretary at the Research Department of Department of research works of the Head Design and Research Institute of the Russian Academy of Sciences (3 Gubkina st., Moscow, 117971. GIPRONII RAN). E-mail: kuleshgal@yandex.ru. 